FOLIA POMERANAE UNIVERSITATIS TECHNOLOGIAE STETINENSIS

Folia Pomer. Univ. Technol. Stetin., Oeconomica 2017, 333(86)1, 63-78

\title{
SYSTEMY ZARZADZANIA ŚRODOWISKOWEGO JAKO SZANSA NA PROMOWANIE ZRÓWNOWAŻONEGO ROZWOJU, ZE SZCZEGÓLNYM UWZGLĘDNIENIEM SYSTEMU EKOZARZĄDZANIA I AUDYTU (EMAS)
}

\author{
THE ENVIRONMENTAL MANAGEMENT SYSTEMS AS A OPPORTUNITY \\ IN PROMOTING SUSTAINABLE DEVELOPMENT WITH SPECIAL EMPHASIS \\ ON THE COMMUNITY ECO-MANAGEMENT AND AUDIT SCHEME (EMAS)
}

Zakład Ekonomii i Rachunkowości, Zachodniopomorski Uniwersytet Technologiczny w Szczecinie ul. Żołnierska 47, 71- 210 Szczecin, e-mail: janusz.myszczyszyn@zut.edu.pl

\begin{abstract}
Summary. The idea of sustainable development is one of the key in the process of economic development for Poland and the world. Human population wants the continuous growth of their consumption, but must recognize the need to protect the environment. Environmental management systems provide the appropriate management culture in the sphere of protection of natural resources in organizations, in their external environment, as well as human behavior. EMAS though still not very popular in our country (70 registered organizations), because it assumes much higher requirements than ISO 14001. Average number of the organizations increasing annually by 5-6. EMAS may in the future play an important role in promoting ecological behavior not only in the economic sphere, but also non-profit organizations and public institutions. The author shows how the benefits of the implementation of the EMAS, but also examines the barriers and difficulties in its start-up. The results of the author's own research carried out in 2016 among representatives of EMAS system.
\end{abstract}

Słowa kluczowe: system ekozarządzania i audytu (EMAS), rozwój zrównoważony, ochrona środowiska.

Key words: Eco-Management and Audit Scheme (EMAS), sustainable development, environmental protection.

\section{WSTĘP}

Rozwój gospodarczy i wzrost dobrobytu społecznego uzależniony jest od dostępnych zasobów naturalnych, jednocześnie wpływając na środowiska (otoczenia), w którym przebywamy.

Przewrót techniczny zapoczątkowany w XVIII w. w Anglii przyczynił się do rozwoju kapitalizmu i niespotykanego wcześniej wzrostu produkcji zarówno w rolnictwie, jak i przemyśle, ale także ujawnił negatywny wpływ człowieka na środowisko naturalne (Myszczyszyn 2010). Mimo to potrzeba ochrony środowiska naturalnego schodziła na dalszy plan. I choć Malicki i Dreszczyk (2001), Runowski (2001) podkreślają, że człowiek potrafił już wcześniej łączyć procesy produkcyjne $z$ ochroną środowiska, to dopiero koniec XX w. i początek XXI w. można określić jako erę poszukiwania nowych strategii rozwoju gospodarczego.

Głównym problemem polityk ekonomicznych stało się zachowanie równowagi pomiędzy wzrostem gospodarczym a koniecznością ochrony środowiska i zachowania nieodnawialnych zasobów przyrody dla przyszłych pokoleń. Tak rozległy zakres działania, obejmujący sferę ekonomiczną, społeczną oraz ekologiczną, został zawarty w idei zrównoważonego rozwoju (Wiatrak 2000; Bartkowiak i Borowiecki 2006). 
Należy podkreślić, że w traktacie UE art. 3 brzmi: „[...] Unia ustanawia rynek wewnętrzny. Działa na rzecz trwałego rozwoju Europy, którego podstawą jest zrównoważony wzrost gospodarczy oraz stabilność cen, społeczna gospodarka rynkowa o wysokiej konkurencyjności zmierzająca do pełnego zatrudnienia i postępu społecznego oraz wysoki poziom ochrony i poprawy jakości środowiska. Wspiera postęp naukowo-techniczny" (Traktat o Unii Europejskiej (wersja skonsolidowana). DzUrz. UE z 26.10.2012 r., C 326).

Autor przyjmuje hipotezę badawczą, że implementacja systemów zarządzania środowiskowego, w tym systemu EMAS, zwiększa świadomość organizacji, instytucji, ich kierownictwa i pracowników, a także społeczeństwa, dotyczącą konieczności dbałości o środowisko naturalne, przyczyniając się do realizacji idei zrównoważonego rozwoju.

Sama koncepcja zrównoważonego rozwoju może okazać się dużo trwalsza, pożądana i budząca mniej kontrowersji od zachodzących procesów globalizacji, gdyż zakłada rozwój gospodarczy, który dokonuje się z poszanowaniem naturalnego środowiska życia człowieka.

Przygotowując artykuł, autor sformułował następujące cele:

- ocena popularności implementacji systemów zarządzania środowiskowego ISO 14001 oraz wspólnotowego systemu zarządzania i audytu EMAS w krajach członkowskich UE, a szczególnie w Polsce;

- ukazanie statystyk dotyczących wdrożeń systemów zarządzania środowiskowego;

- ocena oddziaływania systemów środowiskowych na ciągły wzrost świadomości zrównoważonego rozwoju w naszym kraju;

- przedstawienie głównych korzyści, a także barier, które towarzyszą wdrażaniu systemu EMAS.

Dla weryfikacji hipotezy badawczej i założonych celów autor posłużył się materiałami wtórnymi, m.in. statystykami dostępnymi w unijnym rejestrze EMAS, a także rejestrze prowadzonym przez Generalną Dyrekcję Ochrony Środowiska, deklaracjami środowiskowymi zarejestrowanych w EMAS organizacji i obiektów.

Autor przeprowadził także pilotażowe badania 22 organizacji, które zostały zarejestrowane w systemie EMAS i które są przez niego kontynuowane. W badaniu uczestniczyli pełnomocnicy systemu środowiskowego (w tym EMAS).

\section{POJĘCIE ROZWOJU ZRÓWNOWAŻONEGO}

Termin „rozwój zrównoważony” (sustainable development) pojawił się w raporcie Brundtlanda „Nasza wspólna przyszłość” („Our common future”) w 1987 r. Koncepcja zakładała zachowanie równowagi pomiędzy wzrostem gospodarczym i zaspokajaniem bieżących potrzeb a koniecznością ochrony środowiska i zachowania nieodnawialnych zasobów przyrody dla przyszłych pokoleń. Autor według tego raportu był przekonany, że człowiek na ówczesnym poziomie rozwoju gospodarczego potrafi zapewnić rozwój zrównoważony. ${ }^{1}$

\footnotetext{
1 „Humanity has the ability to make development sustainable to ensure that it meets the needs of the present without compromising the ability of future generations to meet their own needs. The concept of sustainable development does imply limits - not absolute limits but limitations imposed by the present state of technology and social organization on environmental resources and by the ability of the biosphere to absorb the effects of human activities. But technology and social organization can be both managed and improved to make way for a new era of economic growth" (World Commission on Environment\&Development 1987, s. 27).
} 
Kilka lat później w raporcie „The world trade organization and sustainable development” (1996) wskazywano, że - mimo iż nie do końca udało się określić główne przesłanie rozwoju zrównoważonego - światowa gospodarka i jej otoczenie (środowisko) są połączone niczym syjamskie bliźnięta. Postęp w jednej dziedzinie zależy od postępów w drugiej. Handel i liberalizacja bez odpowiednich zabezpieczeń w sferze środowiska doprowadzi do jego degradacji, często na skalę masową. Dlatego pojęcie zrównoważonego rozwoju zawarte jest w preambule do „Porozumienia rundy urugwajskiej” (Agreement establishing..., https://www.wto.org/english/ /res_e/booksp_e/agrmntseries1_wto_e.pdf).

Koncepcja zrównoważonego rozwoju pojawia się zarówno w kluczowych strategiach Unii Europejskiej, jak i w głównych aktach prawnych wielu państw. Na przykład w Konstytucji RP (1997) w art. 5 zapisano: „Rzeczpospolita Polska strzeże niepodległości i nienaruszalności swojego terytorium, zapewnia wolności i prawa człowieka i obywatela oraz bezpieczeństwo obywateli, strzeże dziedzictwa narodowego oraz zapewnia ochronę środowiska, kierując się zasadą zrównoważonego rozwoju".

W przyjętej w dniu 17 czerwca 2010 r. przez Radę Europejską „Strategii Europa 2020 na rzecz wzrostu gospodarczego i zatrudnienia" (Komunikat Komisji Europejskiej... 2010) przyjęto trzy wzajemnie wzmacniające się priorytety:

- wzmocnienie inteligentnego wzrostu;

- zrównoważony rozwój;

- sprzyjanie włączeniu społecznemu.

Dążąc do zapewnienia zrównoważonego wzrostu, założono m.in. budowę konkurencyjnej gospodarki niskoemisyjnej, ochronę środowiska naturalnego, opracowanie nowych przyjaznych dla środowiska technologii.

Tak rozległy zakres działania, obejmujący sferę ekonomiczną, społeczną oraz ekologiczną, wydaje się racjonalną alternatywą dla obywateli poszczególnych części globu. Ideę zrównoważonego rozwoju można traktować jako kontrpropozycję współczesnej globalizacji (Gawor 2006; Myszczyszyn 2015).

W Polsce wcześniej używano pojęcia „ekorozwój”; terminami pokrewnymi do pojęcia „rozwój zrównoważony" są: rozwój trwały, podtrzymywalny, samopotrzymujący się, sustensywny itd. (Mierzejewska 2010). Trzeba jednak dodać, że wielu autorów nie stawia znaku równości pomiędzy tymi stwierdzeniami. Dlatego można przyjąć definicję zawartą w dokumentach Narodów Zjednoczonych, według której równoważony rozwój Ziemi to rozwój, który zaspokaja podstawowe potrzeby wszystkich ludzi oraz zachowuje, chroni i przywraca zdrowie i integralność ekosystemu Ziemi, bez zagrożenia możliwości zaspokojenia potrzeb przyszłych pokoleń i bez przekraczania długookresowych granic pojemności ekosystemu Ziemi (Czech 2009).

\section{ISTOTA SYSTEMÓW ZARZĄDZANIA ŚRODOWISKOWEGO EMAS NA PRZYKŁADZIE ISO 14001}

Konieczność dbałości o otaczające nas środowisko doprowadziła do sformalizowania wymagań dotyczących takiego systemu. Na przestrzeni kilkudziesięciu lat ukształtowało się kilka systemów o międzynarodowym zasięgu. Spośród nich na szczególną uwagę zasługują system zarządzania środowiskowego ISO 14001:2004 (obecnie 14001:2015) i system 
ekozarządzania i audytu określony rozporządzeniem Parlamentu Europejskiego EMAS (Myszczyszyn 2010). Według danych The ISO Survey of Management System Standard Certifications (2014), wśród 1561482 certyfikatów ISO (w 2013 r.) systemy zarządzania środowiskowego zgodne z normą ISO 14001 były mniej popularne jedynie od normy ISO 9001 i stanowiły prawie 19,5\% wszystkich certyfikacji systemów ISO (301 622 certyfikacje).

W 2014 r. nastąpił ponad 7-procentowy wzrost wdrożeń, co tylko świadczy o ciągłym wzroście popularności systemu ISO 14001, a zarazem o konieczności ochrony środowiska naturalnego. Szczególnie zauważalny jest wzrost zainteresowania normą w Ameryce Północnej i Azji. Dla przykładu, w 2014 r. liczba certyfikacji w Chinach wzrosła o 13023. Łącznie tylko w 2014 r. system zarządzania środowiskowego zgodny z normą ISO 14001 wdrożono w 171 krajach świata w liczbie ponad 300 tys. System zarządzanie środowiskowego zgodny z normą ISO 14001 może wdrożyć każda organizacja, niezależnie od formy własności, wielkości, rodzaju działalności. Warunkiem jest to, aby organizacja, która ubiega się o certyfikat, uwzględniła wszystkie istotne kwestie środowiskowe mające związek z prowadzoną działalnością, takie jak: zanieczyszczenie powietrza, kwestie wodno-kanalizacyjne, gospodarowanie odpadami, zanieczyszczenie gleby, łagodzenie zmian klimatu i efektywność wykorzystania zasobów.

Wdrażając system ISO 14001, organizacja m.in. wykazuje zgodność prowadzonej działalności z obowiązującym ustawodawstwem, zwiększone zarządzanie strategiczne i zaangażowanie pracowników oraz ma szansę na poprawę wizerunku. Ważne jest też to, że potrafi osiągać strategiczne cele biznesowe poprzez włączenie problemu ochrony środowiska w zarządzanie przedsiębiorstwem, zwiększenie przewagi w wyniku wzrostu efektywności ekonomicznej, zachęcanie do wzrostu efektywności środowiskowej wśród dostawców (ISO 14001. Key benefits 2015).

Dla powstania i funkcjonowania wspólnotowego systemu ekozarządzania i audytu EMAS (ang. Eco Management and Audit Scheme) kluczowe decyzje w 1993 r. podjęły Parlament Europejski i Rada UE. Przyjęły one pierwsze rozporządzenie dotyczące systemu ekozarządzania i audytu EMAS, który jako dobrowolny wykraczał poza krajowe normy dotyczące ochrony środowiska. Znalazło to swoje odzwierciedlenie w dokumentach programowych UE, m.in. w 5 wspólnotowym programie działania na rzecz środowiska pt. „W stronę zrównoważonego rozwoju" (Towards sustainability), opublikowanym w 1993 r. Za priorytetowe dziedziny uznano m.in.: zrównoważone gospodarowanie zasobami naturalnymi, zintegrowane zwalczanie zanieczyszczeń i zapobieganie powstawaniu odpadów, ograniczenie zużycia energii nieodnawialnej, kompleksowe działania na rzecz poprawy środowiska na terenach miejskich, podniesienie poziomu zdrowotności i bezpieczeństwa publicznego, ze szczególnym uwzględnieniem zagrożeń ze strony przemysłu i instalacji jądrowych. Wiele uwagi poświęcono pięciu sektorom wpływającym w istotny sposób na środowisko, czyli: przemysłowi, energetyce, transportowi, rolnictwu i turystyce (Fifth European Community environment programme: towards sustainability) - Resolution of the Council and the Representatives of the Governments of the Member States, meeting within the Council of 1 February 1993 on a Community programme of policy and action in relation to the environment and sustainable development A European Community programme of policy and action in relation to the environment and sustainable development. DzU 17.05.1993, C 138. 
Parlament Europejski i Rada UE przyjęły pierwsze Rozporządzenie Rady (EWG) 1836/1993 w sprawie wspólnotowego systemu ekozarządzania i audytu EMAS. Zgodnie z ww. rozporządzeniem system EMAS jako dobrowolny kierowany był do spółek sektora przemysłowego. W 2001 r. opublikowano zweryfikowane Rozporządzenie nr 761/2001 Parlamentu Europejskiego i Rady z dnia 19 marca 2001 r. dopuszczające dobrowolny udział organizacji (nie tylko przedsiębiorców) we wspólnotowym systemie ekozarządzania i audytu. Zasadniczym założeniem systemu EMAS jest dobrowolna ciągła poprawa działalności na rzecz ochrony środowiska.

W Polsce system EMAS opierał się (poza samym Rozporządzeniem 761/2001) na Ustawie z dnia 12 marca 2004 r. o krajowym systemie ekozarządzania i audytu (EMAS) oraz na kilku aktach wykonawczych². Obecnie obowiązuje Rozporządzenie Parlamentu Europejskiego i Rady nr 1221/2009 z dnia 25 listopada 2009 r. w sprawie dobrowolnego udziału organizacji w systemie ekozarządzania i audytu we Wspólnocie (EMAS), uchylające rozporządzenie (WE) nr 761/2001 oraz decyzje Komisji 2001/681/WE i 2006/193/WE. Ustawa z dnia 12 marca 2004 r. została uchylona; obecnie obowiązuje Ustawa z dnia 15 lipca 2011 r. w o krajowym systemie ekozarządzania i audytu (EMAS). Zakłada ona m.in., że opłata rejestracyjna (wpis do rejestru EAMS) nie może być wyższa niż 3000 zł; stawka opłaty rejestracyjnej wynosi 1000 zł (art. 7. pkt 1 i pkt 3 Ustawy).

Z kolei wzór wniosku o wpis organizacji do rejestru zawarty jest w Rozporządzeniu Ministra Środowiska z dnia 14 lutego 2012 r. w sprawie wzoru wniosku o rejestrację organizacji w rejestrze EMAS. Wysokość opłaty określona została w Rozporządzeniu Ministra Środowiska z dnia 28 marca 2012 r. w sprawie współczynników różnicujących wysokość opłaty rejestracyjnej za wpis do rejestru organizacji zarejestrowanych w krajowym systemie ekozarządzania i audytu (EMAS). Opłata jest uzależniona m.in. od liczby zatrudnionych pracowników, ale także od rodzaju prowadzonej działalności. Na przykład najniższa opłata rejestracyjna dotyczy organizacji będącej organizacją pozarządową, placówką oświatowo-wychowawczą albo jednostką sektora finansów publicznych; wynosi 0,005 stawki opłaty rejestracyjnej. Maksymalna stawka dotyczy organizacji zatrudniających powyżej 500 osób.

Udział w systemie EMAS jest dobrowolny, a sam system jest dostępny dla wszelkiego rodzaju organizacji. Termin „organizacje” obejmuje przedsiębiorstwa prowadzące działalność produkcyjną, usługową, organy administracji publicznej i instytucje pożytku publicznego. Zakłada się, że EMAS będzie udostępniony wszystkim organizacjom we Wspólnocie i poza nią, których działalność ma wpływ na środowisko. EMAS powinien dostarczyć tym organizacjom środki do zarządzania tym wpływem i poprawy ogólnych efektów ich działalności środowiskowej (pkt 9 Rozporządzenia Parlamentu Europejskiego z 25.11. 2009 r.).

Organizacje chcące uzyskać rejestrację w systemie EMAS muszą spełniać następujące wymagania:

\section{- przeprowadzić przegląd środowiskowy;}

\footnotetext{
2 Rozporządzenie Ministra Środowiska z dnia 23 kwietnia 2004 r. w sprawie wzoru wniosku o wpis podmiotu do rejestru weryfikatorów środowiskowych oraz wzorów dokumentów, formy, częstotliwości i terminów przekazywania informacji z rejestru wojewódzkiego do rejestru krajowego. DzU z 2004 r., nr 94, poz. 930; Rozporządzenie Ministra Środowiska z dnia 23 kwietnia 2004 r. w sprawie zakresu danych, które zawiera rejestr wojewódzki oraz wzór wniosku o rejestrację organizacji w rejestrze wojewódzkim. DzU z 2004 r., nr 94, poz. 931; Rozporządzenie Ministra Środowiska z dnia 23 kwietnia 2004 r. w sprawie współczynników różnicujących wysokość opłaty rejestracyjnej w krajowym systemie ekozarządzania i audytu (EMAS). DzU z 2004 r., nr 94, poz. 932.
} 
- w zależności od wyników przeglądu środowiskowego wdrożyć efektywny system zarządzania środowiskowego;

- przeprowadzić wewnętrzny audyt środowiskowy;

- przygotować deklarację środowiskową opisującą system zarządzania środowiskowego oraz efekty działalności środowiskowej.

Wstępny przegląd środowiskowy, system zarządzania środowiskowego, procedura audytu i jej wdrożenie poddawane są ocenie weryfikatora EMAS, następnie zostaje walidowana deklaracja środowiskowa. Po pozytywnej ocenie możliwe jest wystąpienie o rejestrację organizacji (obiektu) wraz z podaniem do publicznej wiadomości. Odnowienie rejestracji w EMAS następuje przynajmniej raz na 3 lata.

Rozporządzenie EMAS z 2001 r. wprowadziło nowy element, który zwiększa atrakcyjność rejestracji w systemie - logo EMAS. Zgodnie z Rozporządzeniem Parlamentu Europejskiego i Rady (We) nr 1221/2009 z dnia 25 listopada 2009 r. obowiązuje jedno logo EMAS (ryc. 1). Każda organizacja, która wdrożyła system EMAS otrzymuje numer, który jest ujawniany w polu: Reg. No.

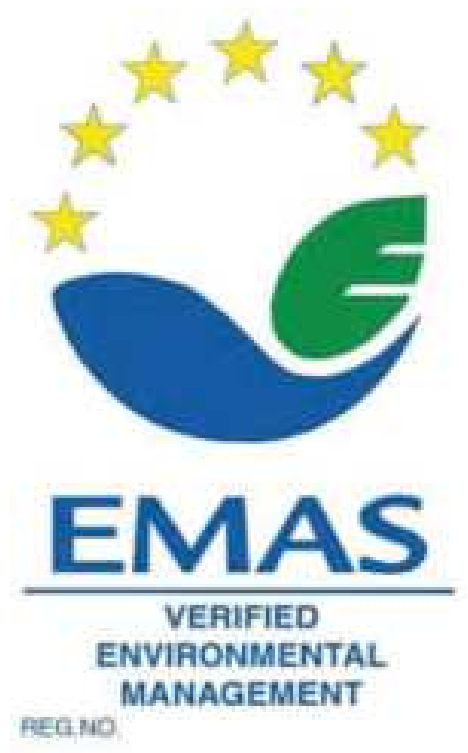

Ryc. 1. Logo systemu EMAS

Źródło: Rozporządzenie Parlamentu Europejskiego i Rady (We) nr 1221/2009 z dnia 25 listopada 2009 r.

Do systemu zarządzania środowiskowego ISO 14001 system EMAS dodaje elementy:

- stałą poprawę działalności prośrodowiskowej poprzez konieczność odnowienia rejestracji, aktualizacji deklaracji środowiskowej i ciągłego wytyczania nowych celów środowiskowych;

- zgodność z prawodawstwem dotyczącym ochrony środowiska, gwarantowaną poprzez udział w systemie organów administracji;

- powszechny dostęp opinii publicznej poprzez jawne publikacje deklaracji środowiskowych, raportów środowiskowych;

- zaangażowanie pracowników i zarządów organizacji (Myszczyszyn 2010). 


\section{OCENA FUNKCJONOWANIA SYSTEMU EMAS W KRAJACH UNII EUROPEJSKIEJ I EUROPEJSKIEGO OBSZARU GOSPODARCZEGO}

W unijnym rejestrze EMAS, (stan na 31.10 .2015 r.) znajdowało się 3928 organizacji i 8908 obiektów (ryc. 2).

Od roku 2009 do roku 2014 liczba zarejestrowanych organizacji zmniejszyła się o 5,8\%. Powodów może być kilka, np. przeniesienie inwestycji do sfery ochrony środowiska jako próba reakcji na światowy kryzys, konieczność ciągłego wyznaczania celów środowiskowych, brak wymiernych korzyści biznesowych. Mimo tego spowolnienia (jak podają autorzy Raportu Eurostat) od roku 2005 do roku 2014 liczba zarejestrowanych organizacji wzrosła o $31 \%$ (ryc. 2).

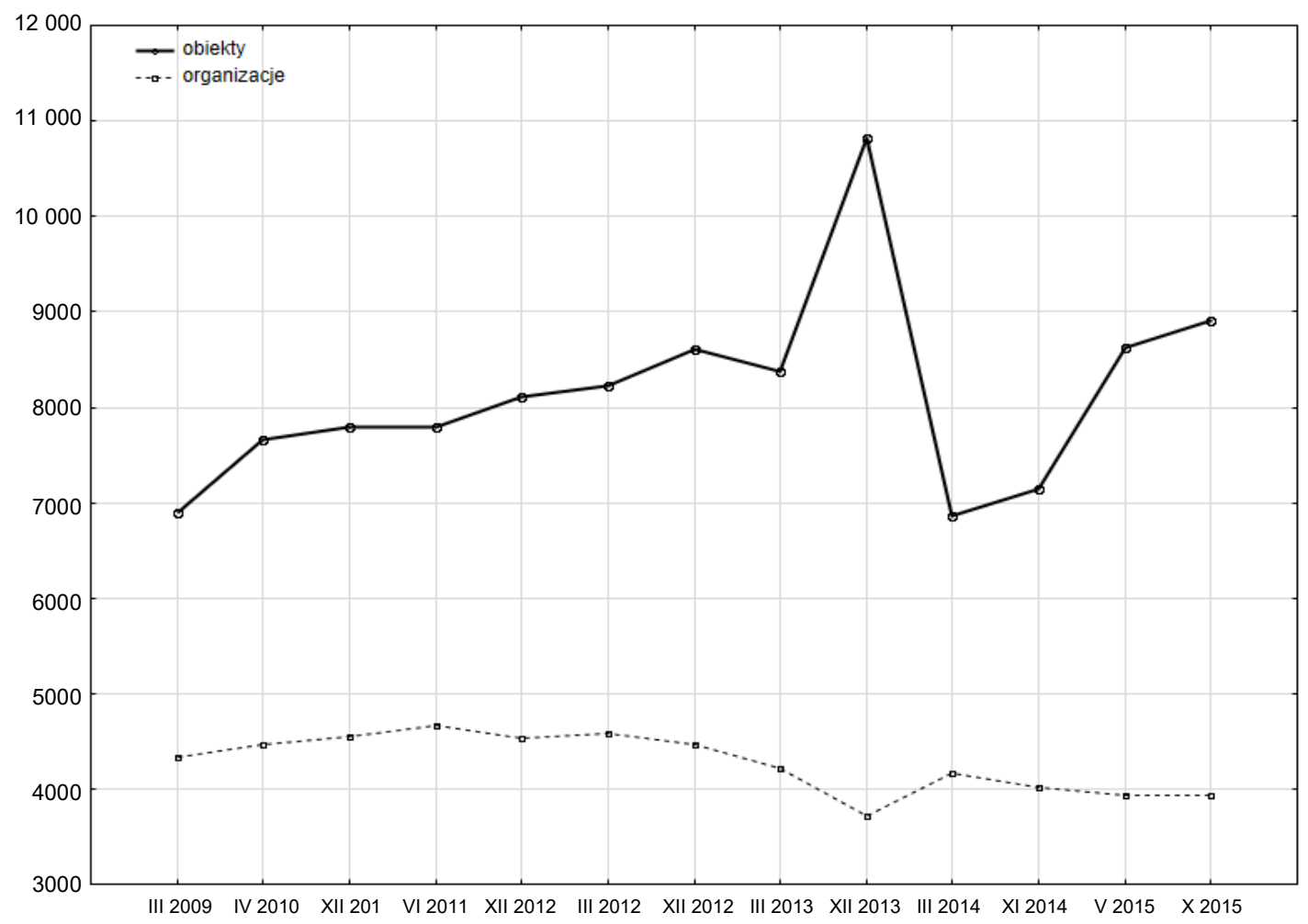

Ryc. 2. Liczba organizacji i obiektów zarejestrowanych w systemie EMAS

Źródło: opracowano na podstawie: Official statistics of the European EMAS Helpdesk - Organisations and sites with EMAS registration, http://ec.europa.eu/environment/emas/register.

W ostatnich latach zauważalny był spadek liczby zarejestrowanych organizacji w kilku państwach członkowskich UE, w których osiągnięto wcześniej wysoki poziom rejestracji, np. nastąpiła silna redukcja w Finlandii (o 90\%), w Szwecji (o 74\%), w Danii (o 43\%) w Wielkiej Brytanii (o 30\%).

Niekwestionowanym liderem pod względem liczby organizacji posiadających EMAS są Niemcy, choć liczba zarejestrowanych organizacji w latach 2005-2014 zmniejszyła się z 1619 do 1229; pod koniec 2015 r. liczba ta wyniosła 1216 (2031 obiektów). Na kolejnych miejscach są: Włochy (964 organizacje, 5790 obiektów), Hiszpania (916 organizacji i 1093 obiekty) - por. Myszczyszyn (2010). 
Wymownym wskaźnikiem, który określa zaangażowanie poszczególnych krajów członkowskich w popularyzacji i implementacji systemu EMAS, a tym samym idei zrównoważonego rozwoju, jest liczba organizacji/obiektów posiadających taki system na milion mieszkańców (ryc. 3).

Wyniki pozwalają stwierdzić, że największą koncentrację wdrożonych systemów EMAS na milion mieszkańców odnotowuje się:

- na Cyprze (62,5 organizacji),

- w Austrii (29,9 organizacji),

- w Hiszpanii (23,5 organizacji),

- w Danii (17 organizacji, 43 obiekty),

- we Włoszech (17,3 organizacji),

- w Niemczech (15,2 organizacji).

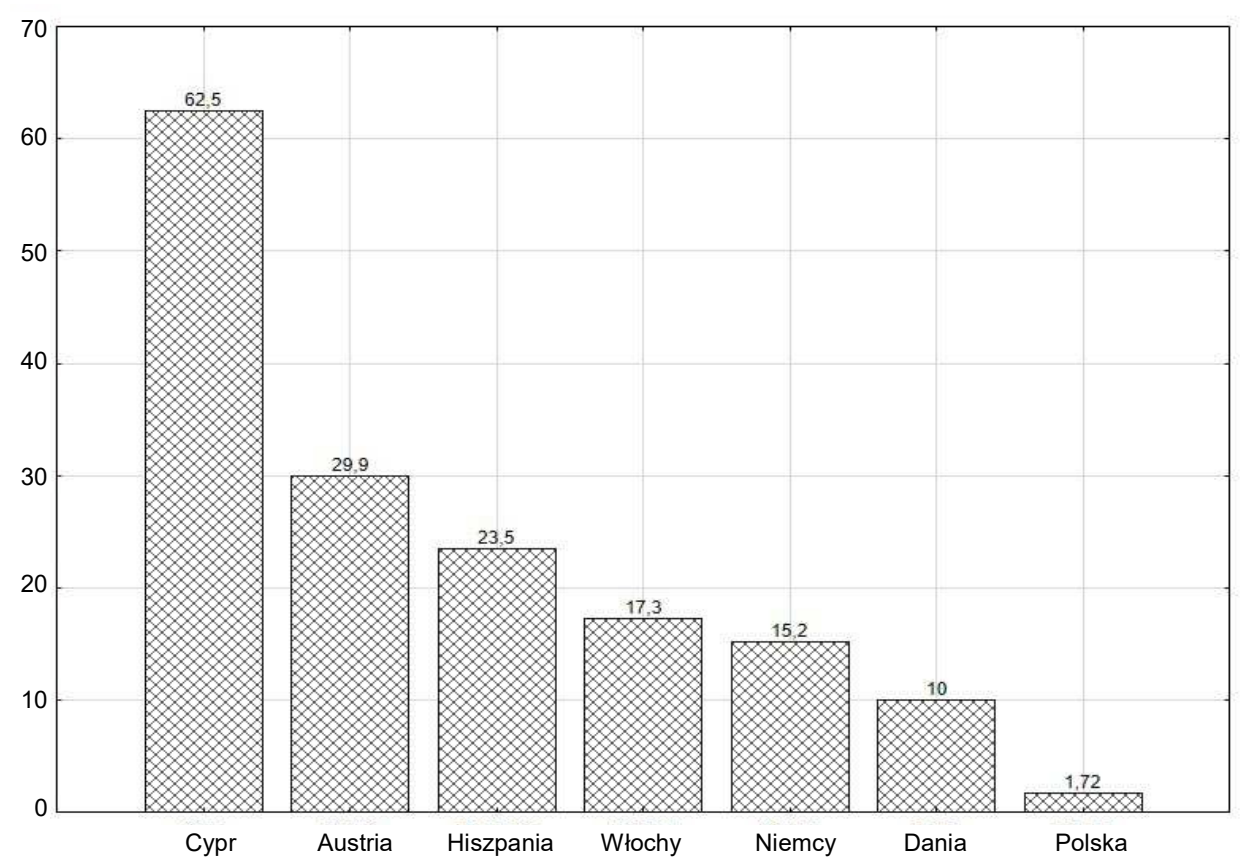

Ryc. 3. Liczba organizacji zarejestrowanych w systemie EMAS przypadająca na $1 \mathrm{mln}$ obywateli w wybranych krajach

Źródło: opracowano na podstawie: Sustainable development in the European Union (2015).

W Polsce jest zaledwie 1,72 organizacji na $1 \mathrm{mln}$ obywateli, co w stosunku do liderów w implementacji systemu EMAS jest ciągle niewiele, ale wobec 0,4 organizacji na $1 \mathrm{mln}$ mieszkańców w 2010 r. odnotowaliśmy niemal czterokrotny wzrost (por. Myszczyszyn 2010).

W okresie od maja 2015 r. do kwietnia 2016 r. system EMAS wdrożono w 243 organizacjach krajów Unii Europejskiej i europejskiego obszaru gospodarczego; najwięcej w Hiszpanii, we Włoszech, w Niemczech, w Polsce i w Austrii.

Jeśli chodzi o wielkość organizacji, statystyki dla UE odnotowują:

- 709 mikrofirm $(18,6 \%)$,

- 1122 małe organizacje $(29,4 \%)$,

\footnotetext{
${ }^{3}$ Łączna liczba organizacji uwzględniona w statystyce wyniosła 3820.
} 
- 1147 średnich organizacji (30\%),

- 842 duże organizacje (22\%).

System EMAS w UE wdrożyły głównie sektory:

- działalność związana ze zbieraniem, z przetwarzaniem i unieszkodliwianiem odpadów; odzysk surowców (470 organizacji);

- administracja publiczna i obrona narodowa; obowiązkowe zabezpieczenia społeczne (394 organizacje);

- wytwarzanie i zaopatrywanie w energię elektryczną, gaz, parę wodną, gorącą wodę i powietrze do układów klimatyzacyjnych (269 organizacji);

- działalność organizacji członkowskich (218 organizacji);

- edukacja (215 organizacji);

- zakwaterowanie (215 organizacji);

- produkcja chemikaliów i wyrobów chemicznych (177 organizacji);

- produkcja metalowych wyrobów gotowych, bez maszyn i urządzeń (159 organizacji).

\section{SYSTEM EMAS W POLSCE - KORZYŚCI I BARIERY}

W Polsce system EMAS do połowy czerwca 2016 r. wdrożyło 70 organizacji i firm; jest to wyraźny postęp w odniesieniu do 17 organizacji zarejestrowanych do końca kwietnia 2009 r. (Myszczyszyn 2010). Zestawienie organizacji zarejestrowanych w EMAS według działów gospodarki narodowej zobrazowano poniżej (ryc. 4). Przeważają organizacje z działu E (działalność związana z rekultywacją i pozostała działalność usługowa związana z gospodarką odpadami - 21 organizacji), z działu O (administracja publiczna i obrona narodowa; obowiązkowe zabezpieczenia społeczne - 19 organizacji) oraz z działu C (przetwórstwo przemysłowe - 14 organizacji). Dział D (wytwarzanie i zaopatrywanie w energię elektryczną, gaz, parę wodną i powietrze do układów klimatyzacyjnych) reprezentowany jest przez 7 organizacji, dział K (działalność finansowa i ubezpieczeniowa) - przez 3 organizacje, działy B (górnictwo i wydobywanie) i Q (opieka zdrowotna i pomoc społeczna) - każdy reprezentowany jest przez 2 organizacje oraz działy $\mathrm{H}$ (transport i gospodarka magazynowa) i F (budownictwo) po jednym przedstawicielu.

W systemie nie odnotowano organizacji z działów:

- A (rolnictwo, łowiectwo i leśnictwo);

- $G$ (handel hurtowy, bez handlu pojazdami samochodowymi);

- P (edukacja).

Wymieniając główne cele środowiskowe, określone w deklaracjach środowiskowych, należałoby, oprócz rodzaju prowadzonej działalności, wyodrębnić: 1) organizacje sektora prywatnego, które dążą do maksymalizacji zysków; 2) organizacje sektora publicznego, które sporządzając swoje deklaracje środowiskowe, uwzględniają m.in. misję społeczną.

Na podstawie deklaracji środowiskowych organizacje sektora prywatnego zarejestrowane w Polsce koncentrują się głównie ${ }^{4}$ na:

- redukcji zanieczyszczeń (emisji) do powietrza i wody (w tym $\mathrm{CO}_{2}$, tlenków azotu);

- zwiększeniu odzysku i recyklingu odpadów opakowaniowych;

\footnotetext{
${ }^{4} \mathrm{Na}$ podstawie deklaracji środowiskowych firm posiadających wdrożony system EMAS.
} 
- optymalizacji zużycia wody;

- redukcji hałasu i wibracji;

- zapobieganiu zanieczyszczeniom, racjonalnej gospodarce odpadami;

- zbiórce większej ilości odpadów niebezpiecznych;

- obniżaniu zużycia surowców (paliw), w tym surowców nieodnawialnych (np. poprzez użycie biomasy);

- ograniczeniu zużycia energii elektrycznej;

- wzroście selektywnej segregacji odpadów;

- zachowanie odpowiedniego stanu środowiska poprzez zrównoważony rozwój;

- działaniach prośrodowiskowych, np. na nowych nasadzeniach drzew, na trawnikach, rekultywacji terenów;

- współpracy z samorządami lokalnymi, ze społecznością lokalną w celu szerzenia polityki ochrony zasobów naturalnych.

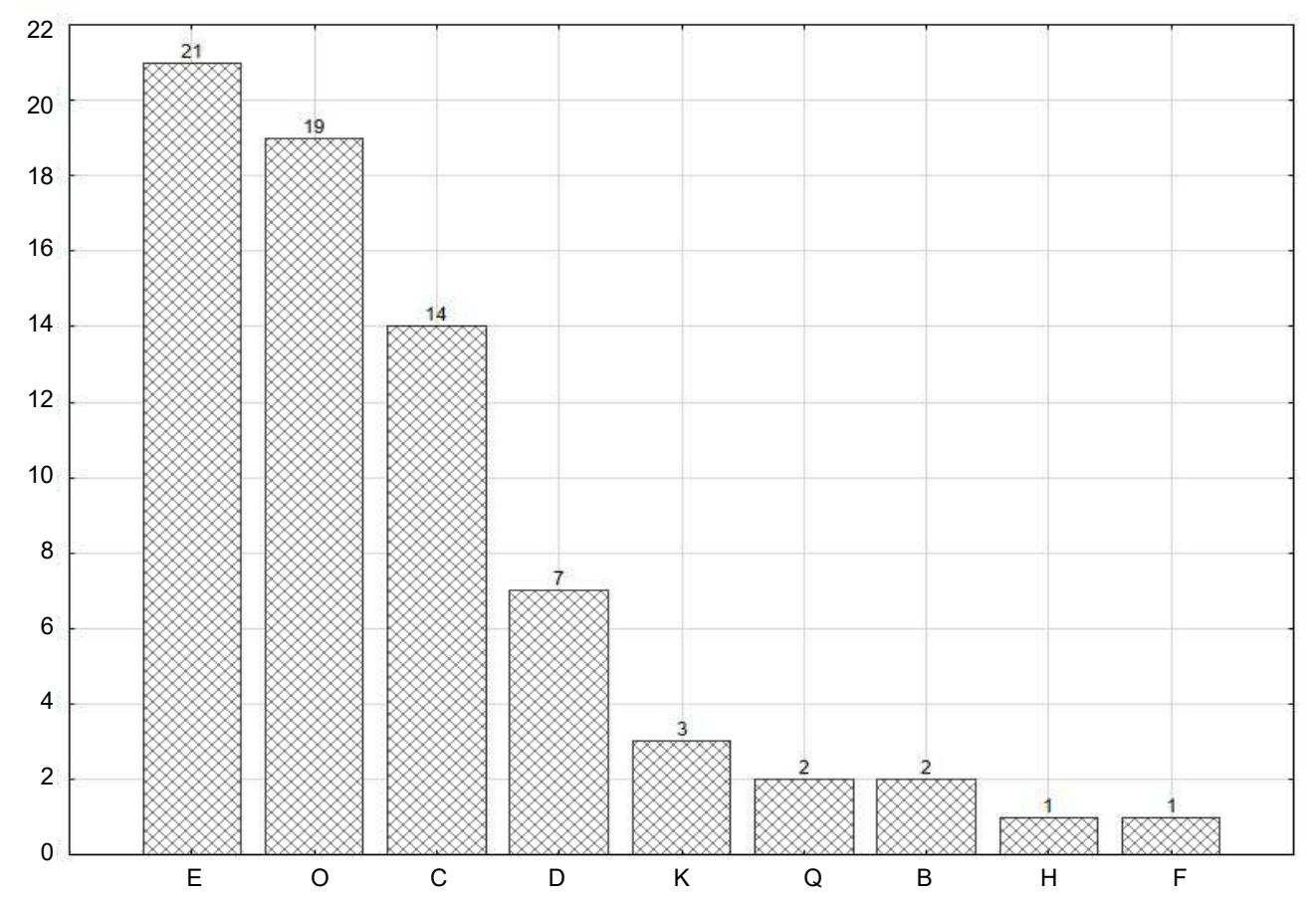

Ryc. 4 Organizacje zarejestrowane w systemie EMAS w Polsce - według działów gospodarki narodowej. E - działalność związana z rekultywacją i pozostała działalność usługowa związana z gospodarką odpadami, $\mathrm{O}$ - administracja publiczna i obrona narodowa, obowiązkowe zabezpieczenia społeczne, C - przetwórstwo przemysłowe, D - wytwarzanie i zaopatrywanie w energię elektryczną, gaz, parę wodną i powietrze do układów klimatyzacyjnych, $\mathrm{K}$ - działalność finansowa i ubezpieczeniowa, $\mathrm{Q}$ - opieka zdrowotna i pomoc społeczna, B - górnictwo i wydobywanie, $\mathrm{H}$ - transport i gospodarka magazynowa, $\mathrm{F}$ - budownictwo

Źródło: opracowano na podstawie: Lista rejestru EMAS, www.emas.gov.pl.

Organizacje pożytku publicznego zarejestrowane w EMAS koncentrowały się głównie na:

- zapewnieniu skutecznej i stabilnej ochrony rezerwatów, zabytków przyrody;

- zapewnieniu zachowania wartości przyrodniczych terenów cennych pod względem przyrodniczym oraz na ochronie fauny i flory;

- zapobieganiu zagrożeniom w środowisku wynikającym z działalności podmiotów korzystających ze środowiska; 
- wywieraniu wpływu na społeczeństwo, dotyczącego konieczności ochrony zagrożonych gatunków zwierząt, roślin;

- ustanowieniu zadań ochronnych dla obszarów Natura 2000;

- kształtowaniu odpowiednich postaw pracowników zmierzających do ograniczania zużycia energii elektrycznej, wody, papieru;

- zapewnieniu społeczeństwu dostępu do informacji o środowisku.

Ważnym celem jest aktywne uczestnictwo pracowników w realizacji poszczególnych zadań dotyczących ochrony środowiska - w szkoleniach, w certyfikacji, w przygotowywaniu deklaracji środowiskowych, w bieżącym funkcjonowaniu firmy, a także w polepszaniu warunków pracy (np. poprzez zmniejszenie czynników uciążliwych, np. natężenia hałasu).

Autor przeprowadził pilotażowe badania własne w 22 organizacjach, które posiadają wdrożony system EMAS. Organizacje ze względu na różnorodny charakter działalności zakwalifikowane zostały do dwóch głównych grup - do organizacji pożytku publicznego, do pozostałych organizacji.

Respondenci pytani byli m.in. o:

- korzyści wynikające z wprowadzenia systemu EMAS;

- słabe strony EMAS, które wpływają na ciągle małe zainteresowanie ze strony polskich organizacji;

- ocenę świadomość społeczeństwa dotyczącą idei zrównoważonego rozwoju;

- plany na przyszłość dotyczące ochrony środowiska.

W organizacjach pożytku publicznego (12 organizacji) głównymi korzyściami z wprowadzenia EMAS, wskazywanymi przez respondentów, były:

- poprawa wizerunku organizacji (wszyscy respondenci);

- wzrost świadomości konieczności prowadzenia działań w sferze ochrony środowiska (10 respondentów);

- ciągłe doskonalenie, a tym samym wpływ na zrównoważony rozwój kraju i świata (8 respondentów);

- inne, w tym: wzrost świadomości pracowników, że mogą mieć wpływ na ochronę środowiska, minimalizacja zużycia zasobów, m.in. papieru (drukowanie, kserowanie), wody, energii elektrycznej i cieplnej, itd., oddziaływanie na inne organizacje, w tym na dostawców, klientów (w tym na petentów).

Badane organizacje w zasadzie nie dostrzegały korzyści ekonomicznych i finansowych z wprowadzenia EMAS lub polepszenia warunków pracy zatrudnionych osób. Jeśli weźmie się pod uwagę ich charakter działalności, to nie jest to zaskoczeniem.

Z kolei w pozostałych badanych organizacjach (sektor prywatny) głównymi korzyściami z wdrożenia EMAS, wskazywanymi przez respondentów, były:

- poprawa wizerunku organizacji (wszyscy respondenci);

- wzrost świadomości konieczności podejmowania działań w sferze środowiska (9 respondentów);

- ciągłe doskonalenie, a tym samym wpływ na zrównoważony rozwój kraju i świata (8 respondentów);

- oddziaływanie na sieć dostawców i odbiorców (6 respondentów); 
- inne, w tym: wpływ na większą konkurencyjność organizacji, korzyści ekonomiczne i finansowe. Wśród korzyści finansowych, jakie przyniosła implementacja EMAS, podawano m.in.:

- zwolnienie z akcyzy (węgiel);

- redukcję odpadów i późniejszych kosztów związanych z ich zagospodarowaniem, utylizacją itd.;

- ograniczenie ilości zużywanych surowców w wyniku zastosowania nowszych, wydajniejszych technologii, bardziej przyjaznych środowisku, redukcję zanieczyszczeń (emisji pyłów, zrzutów do wód itd.), co prowadziło do wzrostu efektywności ekonomicznej, ale też wymagało zwiększenia wydatków inwestycyjnych;

- brak lub redukcja kar płaconych za zanieczyszczenie środowiska;

- prestiż w otoczeniu zewnętrznym, lepszy (ekologiczny) produkt;

- zapewnienie lepszych warunków życia dla otoczenia, w tym społeczności lokalnej, w regionie. Mimo korzyści osiągnięcie celów środowiskowych wymagało poniesienia dodatkowych kosztów (oprócz rejestracji i certyfikacji), które z reguły były wysokie. Założenia systemu EMAS o ciągłym doskonaleniu i weryfikacji zakładanych celów i wyznaczanie kolejnych są trudne dla już zarejestrowanych organizacji i są też przeszkodą dla potencjalnie zainteresowanych. Należy bowiem zakładać ciągłe doskonalenie własnej działalności środowiskowej, która jest weryfikowana np. podczas przeglądów zarządzania i audytów zewnętrznych.

Respondenci wskazywali, że - mimo wymiernych korzyści - system EMAS ma też wady, do których zaliczyli:

- konieczność wyznaczania, dokumentowania i weryfikacji kolejnych celów środowiskowych, co oznacza ponoszenie dodatkowych kosztów; w przypadku dużych inwestycji i wahania wyniku finansowego organizacji cele środowiskowe mogą być trudne do realizacji. W związku z tym niektóre organizacje (również w innych krajach UE) nie decydują się na dłuższe uczestnictwo w systemie;

- konieczność przygotowywania regularnych raportów środowiskowych, które wymagają zaangażowania załogi i zarządów, przy czym działania te mogą kolidować z bieżącą działalnością organizacji;

- wysokie koszty wprowadzenia systemu EMAS, co ma związek nie tylko z opłatą rejestracyjną, ale także z przygotowaniem i wydaniem deklaracji środowiskowej, zaangażowaniem załogi w przygotowanie danych, a także wymaga niezbędnych kosztów, które muszą być poniesione, aby osiągnąć założone cele środowiskowe;

- wysokie koszty funkcjonowania systemu;

- publiczną informację o zakładanych celach środowiskowych, co może w przypadku firm sektora prywatnego oznaczać także pozyskanie niektórych niepożądanych informacji przez konkurencję (np. dotyczących poziomu inwestycji, planów zakupów nowych technologii, oceny dotychczasowych czynników wpływających na ochronę środowiska).

Biorąc pod uwagę uzyskane wyniki badań własnych, a także wcześniejsze publikacje, autor pozytywnie weryfikuje założoną hipotezę badawczą, że implementacja systemów zarządzania środowiskowego, w tym systemu EMAS, zwiększa świadomość organizacji, instytucji, ich kierownictwa i pracowników, a także społeczeństwa, dotyczącą konieczności dbania o środowisko naturalne, co przyczynia się do popularyzacji idei zrównoważonego rozwoju (por. Myszczyszyn 2010). Jak wskazano we wstępie, autor nadal prowadzi badania w organizacjach zarejestrowanych w systemie EMAS. 


\section{WNIOSKI}

Dążenie do zapewnienia trwałego rozwoju gospodarczego oraz unikanie zawirowań i kryzysów ekonomicznych jest jednym z ważniejszych wyzwań współczesnego świata. Niemniej na obecnym etapie rozwoju cywilizacyjnego takie podejście jest niewystarczające. Dążenie do realizacji wyższych potrzeb społecznych bez uwzględniania aspektów środowiskowych jest nieodpowiedzialne, gdyż w konsekwencji może prowadzić do pogorszenia warunków życia ludzi obecnie, a także w przyszłości.

Człowiek wraz z jego gospodarczą działalnością ingeruje w naturalne środowisko i stanowi nieustanne zagrożenie dla otaczających go roślin, zwierząt, mikroorganizmów, atmosfery. Tym samym pogarsza własne środowisko życia. Przyczynami tego zagrożenia są m.in. nieprawidłowe planowanie przestrzenne, stosowanie starych nieefektywnych i uciążliwych dla środowiska technologii, używanie ciągle tańszych, ale nieodnawialnych surowców, nieprawidłowe użytkowanie gruntów, intensywna hodowla zwierząt, która związana jest ze wzmożonym stosowaniem pestycydów, nadmierny hałas itd.

W związku z powyższym implementacja systemu EMAS jest szansą na realizację założeń zrównoważonego rozwoju. Tym bardziej, że funkcjonujące w Polsce organizacje posiadające już system zarządzania środowiskowego, zgodny z normą ISO 14001, mogą przy względnie niewielkim nakładach sił implementować system EMAS.

Mimo wielu korzyści, które przynosi implementacja systemu EMAS i które wskazywali respondenci, nadal istnieje wiele przeszkód we wdrażaniu systemu w naszym kraju; są to m.in.: założenia przyjęte Parlament Europejski i Radę Europy, zawarte w aktach prawnych, do których należy np. wyznaczanie kolejnych mierzalnych celów w sferze ochrony środowiska, upublicznianie deklaracji środowiskowych. Respondenci wskazywali, że w Polsce ciągle jest zbyt mało preferencji ze strony sektora publicznego i instytucji publicznych wobec sektora prywatnego, który angażuje się w ochronę środowiska.

Należy z perspektywy ostatnich kilku lat pozytywnie ocenić zaangażowanie i uczestnictwo w systemie kluczowych organizacji odpowiedzialnych za kreowanie i realizowanie polityki ochrony środowiska, takich jak Ministerstwo Środowiska, regionalne dyrekcje ochrony środowiska. Zaangażowanie ww. instytucji, a także innych organizacji publicznych zwiększa świadomość społeczeństwa, że każda organizacja, niezależnie od formy własności, może niewielkim nakładem sił wpływać na zachowania proekologiczne. Dużą wadą funkcjonowania systemu jest nadal niewielki udział sektora MŚP, brak organizacji sektora rolnictwo i leśnictwo, a nade wszystko brak sektora edukacja.

Nadal niezbędna jest edukacja społeczeństwa poprzez przygotowywanie programów nauczania, środki masowego przekazu, internet i aktywne uczestnictwo szkół, uczelni, instytucji publicznych w promowaniu zachowań proekologicznych. Dla sektora prywatnego zalecane jest tworzenie dodatkowych zachęt na wzór innych krajów UE, które wpływałyby na promocję systemu, tak aby organizacje, które już wdrażają ISO 14001, mogły zwiększyć swoje zaangażowanie środowiskowe, rejestrując się w systemie EMAS. Równie istotne staje się powszechne stosowanie odpowiednich narzędzi do oceny aspektów środowiskowych w ramach idei zrównoważonego rozwoju (Gecevska i in. 2016). 
Pozostaje mieć nadzieję, że w kolejnych latach nastąpi szybszy wzrost implementacji systemu EMAS w naszym kraju, a potrzeba zrównoważonego rozwoju i wzrost gospodarczy Polski będą temu sprzyjać.

\section{PIŚMIENNICTWO}

Agreement establishing the WTO. The WTO Agreements Series, https://www.wto.org/english/ /res_e/booksp_e/agrmntseries1_wto_e.pdf, dostęp: 22.05.2016.

Borowiecki R., Bartkowiak P. 2006. Zmiany własnościowe i organizacyjne w przedsiębiorstwach komunalnych sektora energetycznego i ich wpływ na rozwój zrównoważony. Zesz. Nauk. AE Krak. $731,17$.

Council Regulation (EEC) No 1836/93 of 29 June 1993 allowing voluntary participation by companies in the industrial sector in a Community eco-management and audit scheme. DzU z 10.7.1993 r., L 168.

Czech K. 2009. Rozwój zrównoważony i jego realizacja w warunkach integracji europejskiej na przykładzie Francji, w: Handel międzynarodowy a procesy integracyjne w gospodarce światowej. Red. M. Maciejewski, S. Wydmus. Kraków, Fundacja UE Krak., 43-44.

Gawor L. 2006. Antyglobalizm, alterglobalizm i filozofia zrównoważonego rozwoju jako globalizacyjne alternatywy. Probl. Ekorozw. 1(1), 41-48.

Gecevska V., Donev V., Polenakovik R. 2016. A review of environmental tools towards sustainable development. Ann. Fac. Eng. Hunedoara - Inter. J. Eng. 14(1), 147-152.

ISO 14001. Key benefits. 2015. Genewa, International Organization for Standardization.

Konstytucja Rzeczpospolitej Polskiej. DzU z 1997 r., nr 78, poz. 483 z późn. zm.

Malicki M., Dreszczyk E. 2001. Bezpieczeństwo środowiska na terenach niezurbanizowanych, w: Gospodarka, człowiek, środowisko na obszarach wiejskich. Red. M. Kłodziński, Warszawa, PAN.

Mierzejewska L. 2010. Rozwój zrównoważony miasta. Zagadnienia poznawcze i praktyczne, Poznań, Wydaw. UAM.

Myszczyszyn J. 2010. Polskie doświadczenia w implementacji wspólnotowego systemu ekozarządzania i audytu w świetle najnowszego rozporządzenia EMAS III. Ochr. Środ. Zas. Natural. 44, 44-50.

Myszczyszyn J. 2010. Próba oceny korzyści i barier związanych z implementacją wspólnotowego systemu ekozarządzania i audytu (EMAS). Folia Pomer. Univ. Technol. Stetin., Oeconomica 277(58), $59-72$.

Myszczyszyn J. 2015. Oddziaływanie polityki handlu zagranicznego w kształtowaniu współczesnych procesów globalizacyjnych na przykładzie wybranych gospodarek z wczesnym take-off. Kult. Hist. Global. 18, 191-193.

O krajowym systemie ekozarządzania i audytu (EMAS). DzU z 12.03.2004 r., nr 70, poz. 631, z późn. zm.

Official statistics of the European EMAS Helpdesk - Organisations and sites with EMAS, http://ec.europa.eu/environment/emas/register, dostęp: kwiecień 2016.

Organziations per one milion inhabitants, http://ec.europa.eu/environment/emas/documents/ articles_en.htm, dostęp: kwiecień 2016.

Resolution of the Council and the Representatives of the Governments of the Member States, meeting within the Council of 1 February 1993 on a Community programme of policy and action in relation to the environment and sustainable development - A European Community programme of policy and action in relation to the environment and sustainable development. DzU 17.05.1993, C 138.

Rosicki R. 2010. Międzynarodowe i europejskie koncepcje zrównoważonego rozwoju. Prz. Nauk.-Met. 4, 44-56. 
Rozporządzenie (WE) nr 761/2001 Parlamentu Europejskiego i Rady z dnia 19 marca $2001 \mathrm{r}$. dopuszczające dobrowolny udział organizacji w systemie zarządzania środowiskiem i audytu środowiskowego we Wspólnocie (EMAS). DzU z 24.04.2001 r., L 114.

Rozporządzenie Ministra Środowiska z dnia 14 lutego 2012 r. w sprawie wzoru wniosku o rejestrację organizacji w rejestrze EMAS. DzU z 2012 r., nr 0, poz. 166.

Rozporządzenie Ministra Środowiska z dnia 28 marca 2012 r. w sprawie współczynników różnicujących wysokość opłaty rejestracyjnej za wpis do rejestru organizacji zarejestrowanych w krajowym systemie ekozarządzania i audytu (EMAS). DzU z 2012 r., nr 0, poz. 341.

Rozporządzenie Ministra Środowiska z dnia 23 kwietnia 2004 r. w sprawie wzoru wniosku o wpis podmiotu do rejestru weryfikatorów środowiskowych oraz wzorów dokumentów, formy, częstotliwości $\mathrm{i}$ terminów przekazywania informacji $z$ rejestru wojewódzkiego do rejestru krajowego. DzU z 2004 r., nr 94, poz. 930.

Rozporządzenie Ministra Środowiska z dnia 23 kwietnia 2004 r. w sprawie zakresu danych, które zawiera rejestr wojewódzki oraz wzoru wniosku o rejestrację organizacji w rejestrze wojewódzkim. DzU z 2004 r., nr 94, poz. 931.

Rozporządzenie Ministra Środowiska z dnia 23 kwietnia 2004 r. w sprawie współczynników różnicujących wysokość opłaty rejestracyjnej w krajowym systemie ekozarządzania $i$ audytu (EMAS). DzU z 2004 r., nr 94, poz. 932.

Rozporządzenie Parlamentu Europejskiego i Rady (WE) nr 1221/2009 z dnia 25 listopada 2009 r. w sprawie dobrowolnego udziału organizacji w systemie ekozarządzania i audytu we Wspólnocie (EMAS), uchylające rozporządzenie (WE) nr 761/2001 oraz decyzje Komisji 2001/681/WE i 2006/193/WE. DzU z 22.12.2009 r., L 342.

Rozporządzenie Parlamentu Europejskiego i Rady (We) nr 1221/2009 z dnia 25 listopada 2009 r. w sprawie dobrowolnego udziału organizacji $w$ systemie ekozarządzania $i$ audytu we Wspólnocie (EMAS). DzUrz. UE z 22.12.2009 r., L342/1.

Runowski H. 2001. Zrównoważony rozwój gospodarstw i przedsiębiorstw rolniczych, w: Gospodarka, człowiek, środowisko na obszarach wiejskich. Red. M. Kłodziński. Warszawa, PAN.

Sustainable development in the European Union. Monitoring report of the EU Sustainable Development Strategy. 2015. Luxembourg, Eurostat, Publications Office of the European Union, 105.

The ISO Survey of Management System Standard Certifications. 2014, http://www.iso.org/iso/iso_ _survey_executive-summary.pdf, dostęp: maj 2015.

The World Trade Organization and Sustainable Development: An independent assessment. A report by the International Institute for Sustainable Development. 1996. Winnipeg, Manitoba, International Institute for Sustainable Development.

Traktat o Unii Europejskiej (wersja skonsolidowana). DzUrz. UE z 26.10.2012 r., C 326.

Ustawa $z$ dnia 12 marca 2004 r. o krajowym systemie ekozarządzania i audytu (EMAS). DzU z 2004 r., nr 70 poz. 631, z późn. zm.

Ustawa z dnia 15 lipca 2011 r. o krajowym systemie ekozarządzania i audytu (EMAS). DzU z 2011 r., nr 178, poz. 1060.

Wiatrak A. 2000. Założenia i polityka zrównoważonego rozwoju rolnictwa. Zesz. Nauk. SGGW Warsz. 40, 5-16.

World Commission on Environment \& Development. 1987. Our Common Future. Oxford, Oxford University Press, 27. 
